\section{УДК: 351}

https://doi.org/10.32689/2617-22242020-2(22)-221-229

Шинькович Андрій Васильович, аспірант кафедри публічного адміністрування, Міжрегіональна Академія управління персоналом, 03039 м. Київ, вул. Фрометівська, 2, тел. (067)364-81-68, е-таil: shinkovich7@icloud.com, org/0000-0003-2513-1640

Шинькович Андрей Васильевич, аспирант кафедры публичного администрирования, Межрегиональная Академия управлення персоналом, 03039, г. Киев, ул. Фрометовская, 2, тел. (067)364-8168, e-mail: shinkovich7@icloud.com, https// orcid.org/0000-0003-2513-1640

ORCID: 0000-0002-8935-3253

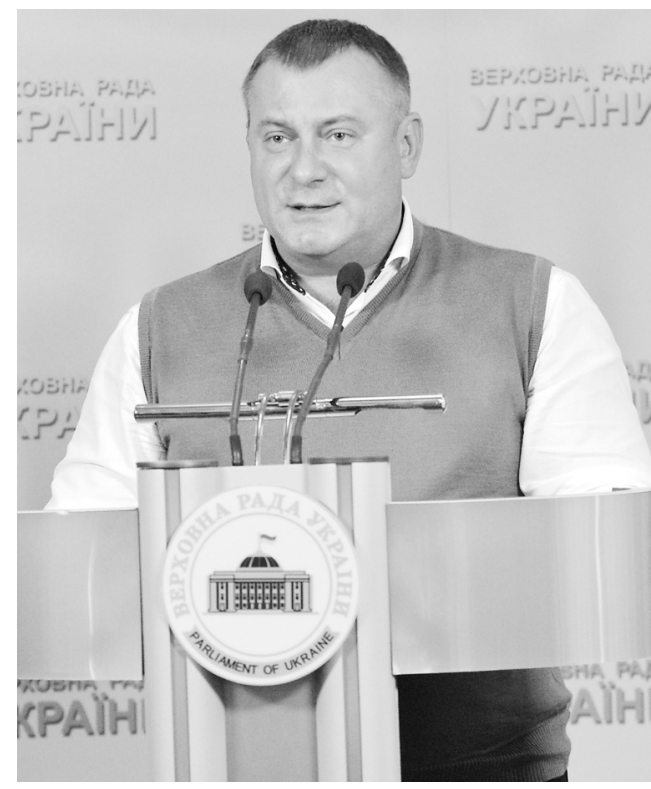

Shinkovich Andriy Vasilovich,

Post-graduate student of the Department of Public Administration, Interrigional Academy of Personnel Management, 03039, Kyiv, Str. Frometivska, 2, tel. (067) 364-81-68, e-mail: shinkovich7@icloud.com, https//orcid.org/0000-0003-2513-1640

\title{
ПРИНЦИП СУБСИДІАРНОСТІ ЯК БАЗОВА ЗАСАДА ПОДІЛУ ВЛАДИ ТА РОЗПОДІЛУ ПОВНОВАЖЕНЬ МІЖ ДЕРЖАВНОЮ ВЛАДОЮ I МІСЦЕВИМ САМОВРЯДУВАННЯМ
}

Анотація. Розглядаються питання, пов'язані із сутнісними особливостями субсидіарності як важливішого принципу поділу влади і розподілу владних повноважень. Увага акцентується на тому, що субсидіарність забезпечує ефективне функціонування влади, що дає можливість максимально демократизувати, децентралізувати державне управління за рахунок якомога дієвішої діяльності місцевого самоврядування. Доводиться, що взаємодія між державними органами влади і органами місцевого самоврядування базується на ряді принципів, які поділяють владу і розділяють владні повноваження i, одночасно, забезпечують цілісність, єдність державної влади. Обгрунтовуються положення, пов'язані з правовим закріпленням розмежованих повноважень державної влади і місцевого самоврядування. Підкреслюється, що існує різна практика надання центром повноважень органам місцевого самоврядування: принцип позитивного регулювання, принцип негативного 
регулювання. Розкриваються особливості двох способів вибудови взаємин центру і регіонів: а) делегування повноважень; б) передача повноважень 3 поясненням їх специфіки та особливостей. Робиться акцент на тому, що центральні органи державної влади передають на місця ті державні повноваження, які оптимальніше вирішуються саме місцевими самоврядними органами і структурами і які, до того ж, нераціонально вирішувати в центрі. Пояснюється характер і особливості механізмів взаємодії органів державної влади і органів місцевого самоврядування, завдяки якому є можливість залучати до питань і процесів державного управління максимальну кількість громадян, а також підвищувати роль громадянського суспільства в управлінні справами держави і суспільства.

Ключові слова: субсидіарність, поділ влади і розподіл владних повноважень, принципи взаємодії органів влади і органів місцевого самоврядування, способи надання центром повноважень місцевому самоврядуванню.

\section{ПРИНЦИП СУБСИДИАРНОСТИ КАК БАЗОВАЯ ЗАСАДА РАЗДЕЛЕНИЯ ВЛАСТЕЙ И РАСПРЕДЕЛЕНИЯ ПОЛНОМОЧИЙ МЕЖДУ ГОСУДАРСТВЕННОЙ ВЛАСТЬЮ И МЕСТНЫМ САМОУПРАВЛЕНИЕМ}

Аннотация. Рассматриваются вопросы, связанные с сущностными особенностями субсидиарности как важного принципа разделения властей и распределения властных полномочий. Делается акцент на том, что субсидиарность обеспечивает эффективное функционирование власти, дает возможность максимально демократизировать, децентрализовать государственное управление за счет как можно более действенной деятельности местного самоуправления. Доказывается, что взаимодействие между государственными органами власти и органами местного самоуправления базируется на ряде принципов, которые разделяют власть и властные полномочия и, одновременно, обеспечивают целостность, единство государственной власти. Обосновываются положения, связанные с правовым закреплением разграниченных полномочий государственной власти и местного самоуправления. Подчеркивается, что существует разная практика предоставления центром полномочий органам местного самоуправления: принцип позитивного регулирования, принцип негативного регулирования. Раскрываются особенности двух способов выстрвивания отношений центра и регионов: а) делегирование полномочий; б) передача полномочий с объяснением их специфики и особенностей. Делается акцент на том, что центральные органы государственной власти передают на места те государственные полномочия, которые оптимально решаются именно местными самоуправляющимися органами и структурами и которые, к тому же, нерационально решать в центре. Объясняется характер и особенности механизмов взаимодействия органов государственной власти и органов местного самоуправления, благодаря которому есть возможность привлекать к вопросам и процессам государственного 
управления максимальное количество граждан, а также повышать роль гражданского общества в управлении делами государства и общества.

Ключевые слова: субсидиарность, разделение властей и распределение властных полномочий, принципы взаимодействия органов власти и органов местного самоуправления, способы предоставления центром полномочий местному самоуправлению.

\title{
THE PRINCIPLE OF SUBSIDIARITY AS A FOUNDATION FOR SEPARATION OF POWER AND DISTRIBUTION OF AUTHORITY BETWEEN GOVERNMENT AND LOCAL SELF-GOVERNMENT
}

\begin{abstract}
The paper considers issues related to the essential features of subsidiarity as an important principle for separation of power and distribution of authority. Emphasis is placed on the fact that subsidiarity ensures the effective functioning of the government and makes it possible to maximize the democratization and decentralization of public administration through the most effective activity of local self-government. The interaction between the state and local self-governments is proved to depend on many principles that divide power and authority and, at the same time, ensure the integrity and unity of the state power. The paper explains provisions related to the legalization of authority distributed between the state power and local self-government. The fact that central power practices different ways of vesting local self-government with authority (the principle of positive regulation and the principle of negative regulation) is emphasized. The features of two ways of building a relationship between centre and regions: a) delegation of authority and b) assignment of authority with an explanation of their specifics and features are revealed. Emphasis is placed on the fact that central bodies of state power delegate locally those powers that are more optimally resolved by local self-governments and structures and which also are irrational to decide in the centre. The nature and peculiarities of the mechanisms of interaction between public authorities and local self-governments are explained. Such interaction makes it possible to involve the maximum number of citizens in the issues and processes of public administration and, thus, increases the role of civil society in managing the affairs of the state and society.
\end{abstract}

Keywords: subsidiarity, separation of power and distribution of authority, principles of interaction between public authorities and local self-governments, methods the centre vests local self-governments with authority

Постановка проблеми. На сьогодні, існує специфічний практичний механізм взаємодії органів державної влади і органів місцевого самоврядування, основу якого, окрім прямих контактів, становить співробітництво за рахунок діяльності різноманітних союзів і асоціацій муніципальних утворень. Саме через такі структури державна влада має 
можливість виходу на максимальну кількість громадян, врешті, це механізм зв'язку держави з громадянським суспільством в цілому. Крім того, останнім часом набула великого поширення практика створення різноманітних узгоджувальних, координаційних, консультативних, дорадчих (тимчасових і постійних) робочих груп, рад, комісій і т. ін., за рахунок діяльності яких державна політика набуває все більшої публічності й відкритості, що, у свою чергу, потребує детальнішого наукового дослідження.

Аналіз останніх досліджень і публікацій. Принцип субсидіарності, як суспільно-політичний феномен достатньо предметно досліджується такими сучасними зарубіжними й вітчизняними вченими як Н. Анісімова, А. Ароян, Веймер, Л. Девід, Р. Вайнінг, Н. Гайдаєнко, О. Гьофе, Е. Каракулян, В. Куйбіда, В. Малиновський, Н. Нижнюк, Т. Панченко, О. Радченко, В. Тертичка, В. Халіпов. Ще більшу кількість робіт маємо 3 організації місцевого самоврядування, з поміж яких виділяються роботи О. Батанова, П. Білейчука, М. Бориславської, М. Головатого, А. Костенко, О. Лазар, В. Малиновського, А. Некряч, I. Погорєлової, В. У твенка та ін.

Формування цілей статті. Метою статті є систематизація поглядів на принцип субсідіарності, як дієвого засобу зміцнення державної влади шляхом поділу влади та розподілу владних повноважень. Вчиняється спроба дати обгрунтування за рахунок реалізації яких складових поділ влади між центром і регіонами може бути максимально плідним і резуль- тативним в інтересах людини, держави і суспільства одночасно.

Виклад основного матеріалу. Історична генеза сучасних країн i суспільств беззаперечно доводить, що поділ влади і розподіл владних повноважень, найперше між державними органами влади і органами місцевого самоврядування є важливішою умовою прогресивного суспільного розвитку. У науковому плані цей принцип (процес) набув назви “субсидіарність".

Об'єктивне право на життя принципу субсидіарності обумовлене тим, що державна влада, повноваження її органів, не можуть бути об'єктивно зосередженими у якомусь одному місці, а, понад усе, поширюватися на усі державно-управлінські рішення й процеси. В умовах демократизації суспільного життя, децентралізації державного управління, зростання ролі громадянського суспільства в функціонуванні великих соціумів, субсидіарність постає принципом (механізмом) оптимального впорядкування відносин між різнорівневими елементами соціальної ієрархії у державі. По-друге, складові елементи будь-якої соціальної системи не можуть позбавитися “абсолютно” впливу центру, бо без нього, його допомоги й підтримки вони не зможуть вижити, плідно існувати. По-третє, є потреба, щоб повноваження передавалися з центру до регіону за умови, коли в регіоні вони будуть найрезультативніше зреалізовані. По-четверте, існує необхідність обопільної відповідальності центру і регіонів за успішну реалізацію державної політики, коли інтереси центру і регіону максимально взаємоузгоджуються. 
По-п'яте, дієвість принципу субсидіарності є найбільш вагомою, коли існує конкуренція компетентності між центром і регіонами [1].

Термінологічно маємо враховувати, що поділ влади - це її поділ між основними гілками влади у державі, а розподіл владних повноважень це розподіл влади (владних повноважень) між центром і регіонами. Обидва ці процеси пов'язані із формуванням публічного управління, яке базується на розвитку скоріше горизонтальних ніж вертикальних зв'язків між владою і громадянським суспільством.

Принцип субсидіарності передбачає обов'язкове розмежування повноважень органів місцевого самоврядування і органів державної влади, хоча взаємодія між ними завжди була і буде. Йдеться про наявність перш за все сукупності організаційно-правових норм і методів, які, у сукупності спрямовані на спільне вирішення як державних так і місцевих завдань. I у першому, і у другому випадку в центрі таких поділу і взаємодії знаходяться права і інтереси людини, громадянина.

В теоретико-практичному плані взаємодія між державними органами влади і органами місцевого самоврядування базується на таких основних принципах:

- єдність цілей і завдань, спрямованих на забезпечення прав і свобод людини і громадянина, а, відтак, реалізації загальнодержавних інтересів;

- всебічна підтримка державою здійснення і розвитку місцевого самоврядування (фінансова, політична, організаційно-управлінська і т. ін.);
- розведення (одночасно) предметів ведення та владних повноважень між органами державної влади і органами місцевого самоврядування;

- максимальна самостійність (самоврядність) здійснення місцевим самоврядуванням, його органами, посадовими особами своїх повноважень;

- невтручання органів державної влади в компетенцію і практичну діяльність органів місцевого самоврядування (контрольні функції державної влади над місцевим самоврядуванням, однак, залишаються i чітко визначаються законодавчо);

- субсидіарність в процесі здійснення органами місцевого самоврядування мінімальних державних стандартів і переданих їм окремих державних повноважень;

- гласність і інформованість;

- взаємний контроль за діяльністю;

- розв'язання наявних колізій шляхом узгоджених процедура або оскарження в судовому порядку;

- цілеспрямованість і дотримання загальнодержавних інтересів;

- забезпеченість ресурсами місцевого самоврядування.

Державна підтримка місцевого самоврядування закріплюється законодавчо і здійснюється у таких загально прийнятних формах:

- розробка і прийняття відповідних правових актів з питань функціонування місцевого самоврядування;

- контроль за дотриманням місцевим самоврядуванням відповідних конституційних норм, пов'язаних із його діяльністю; 
- належне інформаційне забезпечення органів місцевого самоврядування;

- методична допомога органам місцевого самоврядування;

- участь у формуванні органів місцевого самоврядування у встановлених законом випадках;

- підготовка кадрів для муніципальних органів управління;

- матеріальна і фінансова допомога органам місцевого самоврядування.

Законодавчо органи місцевого самоврядування отримують окремі державні повноваження шляхом виключення таких повноважень із компетенцій державних органів. При цьому важливо враховувати, що світова практика надання центром повноважень органам місцевого самоврядування здійснюється, головним чином, у два способи. Перший спосіб притаманний країнам англосаксонської системи і іменується він, як принцип inter vires - принцип позитивного регулювання. Йдеться про закріплення за органами місцевого самоврядування саме тих повноважень, що визначені відповідним законом. Якщо орган місцевого самоврядування діє не у відповідності із законом, такі дії розцінюються як позазаконні. Інший, протилежний принцип так званого “негативного регулювання" (ultra vires), - континентальний, має місце тоді, коли органи місцевого самоврядування роблять усе, що не забороняється законом і не відноситься до компетенції інших органів.

Якщо здійснювати порівняльний аналіз вище означених підходів, то принцип континентальної системи нібито надає місцевому самоврядуванню більше свободи у його функціонуванні, тому що органи такого врядування мають можливість фактично самостійно визначати міру своєї компетентності. Разом 3 тим окремі фахівці [2; 3; 4-6] вказують на те, що в такій ситуації органи місцевого самоврядування виявляються менше захищеними від довільного зменшення об'єму своїх повноважень, оскільки держава, на свою догоду, може у той чи інший спосіб розширити сферу своєї компетентності. Достатньо часто, в односторонньому порядку законодавчо вищі органи влади держави дійсно у такий спосіб і чинять. Що ж стосується англосаксонської системи поділу повноважень, то зробити такий поділ повноважень в односторонньому порядку досить складно, оскільки норми, що визначають компетенцію муніципальних утворень, закріплюються перш за все у їх статутах, які мають відповідну юридичну силу, i, якщо навіть національне законодавство у будь-який спосіб змінюється, статути місцевих органів влади зміні не підлягають. Така практика існує у багатьох, найперше, - європейських країнах.

Підкреслимо і те, що теорія і практика реалізації місцевого самоврядування передбачає дві форми наділення такого врядування окремими державними повноваженнями: делегування і передача повноважень, що не є ідентичними процедурами. Делегування повноважень - це надання конкретними органами державної влади належного права вирішення питань органу місцевого самоврядування. Підкреслимо, надання 
одноразово, з визначенням певних часових проміжків (термінів) або ж безстроково. Що стосується передачі повноважень, то йдеться про те, що певні повноваження виключаються із компетенції центру і передаються органу місцевого самоврядування, включаючись у його компетенцію. Термін передачі таких повноважень, як правило, не обумовлюється.

За вказаних особливостей “делегування повноважень" i “передача повноважень” маємо характеризувати, як достатньо різні політико-адміністративні процедури. Так, окрім конституційного наділення правами органів місцевого самоврядування у сучасній Україні Закон “Про місцеве самоврядування в Україні” зазначає, що в компетенцію органів місцевого самоврядування можуть входити i окремі державні повноваження, що їм передаються державою [4]. Зазначено, однак, що надання органам місцевого самоврядування таких певних державних повноважень, здійснюється лише законодавчим шляхом.

Суттєве значення має і те, які за характером, особливостями державні повноваження найчастіше передаються органами державної влади органам місцевого самоврядування за раціональною необхідністю. Міжнародна і національна практики засвідчують, що до таких повноважень в першу чергу відносяться:

- питання державної реєстрації актів громадянського стану;

- ліцензування (продажу алкогольної продукції; діяльності по заготівлі, переробці і практичній реалізації лому кольорових та чорних металів; освітня діяльність закладів, що знаходяться на території муніципалітетів);

- організація різного характеру компенсаційних послуг;

- проведення медико-соціальних експертиз;

- здійснення державного містобудівного кадастру і моніторингу об'єктів містобудівної діяльності;

- встановлення значень окремих корегуючи коефіцієнтів при розрахунку єдиного податку на прибуток для певних видів діяльності;

- порядок користування окремими природними ресурсами;

- організація діяльності різних адміністративних комісій і т. ін.

Зрозуміло, що за відповідних умов, як вказувалося, органи місцевого самоврядування позбавляються переданих їм повноважень, що також регулюється законодавчим способом.

Важливо звернути увагу врешті й на те, що в самій теорії муніципального управління сформувалися в цілому три основних моделі взаємодії муніципального управління 3 органами державної влади: 1) модель партнерства (Дж. Ст. Мілль XIX ст.) - певною мірою ідеалістична модель “рівного” партнерства; 2) агентська модель (протилежна партнерській) - тут йдеться про домінуючу роль у державному управлінні вищих державних органів влади, а місцеве самоврядування (управління) розглядається всього лише як певний адміністративний засіб здійснення управлінських функцій на місцях. Певну “усереджену” модель взаємодії центру i місцевої громади становить “модель взаємозалежності”. Скоріше всього 
така модель є на сьогодні найбільш прийнятною i раціональною, якщо брати до уваги помітний розвиток та поширення таких основних видів зв’язку державної влади і місцевого самоврядування як: субординаційні (упорядковані зверху - донизу); координаційні (носять, здебільшого, горизонтальний характер); ре ординаційні (багато в чому подібні на субординаційні).

Підкреслимо, що основи взаємодії органів державної влади і місцевого самоврядування в Україні закладено у Конституції України [5] через систему гарантій, підтримки і захисту функціонування місцевого самоврядування.

Висновки з даного дослідження i перспективи подалыших розвідок. Таким чином доходимо висновку, що принцип субсидіарності нині все більше досліджується, як важливіший фактор збереження цілісності державної влади саме за рахунок поділу влади і розподілу владних повноважень. Викликає великий науковий інтерес те, у який спосіб і наскільки вирішальним чином впливатимуть на процеси субсидіарності демократизація суспільних відносин та децентралізація державного управління, зростання впливу на державно-управлінські процеси громадянського суспільства. Коло окреслених проблем пронизують політологічні, соціологічні, маркетингові та інші особливості вище вказаних процесів, які потребують ще більш поглибленого і предметного аналізу. Без сумніву, йде процес радикальної трансформації, в тому числі і за рахунок практичної реалізації принципу субсидіарності, сучасних моделей державного управління, в тому числі і у новітній Україні.

\section{СПИСОК ВИКОРИСТАНИХ ДЖЕРЕЛ}

1. Большаков С. Н. Принцип субсидиарности в современном демократическом управлении: концептуальные подходы и проблемы практической реализации. Автореф. дис. ... д-ра полит. наук. 23.00.02 политические институты и процессы. СПб. 2006.40 с.

2. Говорук Д. М. Поняття принципу публічності та його нормативний аспект [Електронний ресурс]. Режим доступу: http://nauka.nueau.org.ua/ gow uload//elzbirnik/1/covorun.pdf

3. Дегтяр О. А. Роль системи публичного управленния в социальній сфере общества // Публічне урядування. № 1 (2) - березень 2016. Київ. ДП “Вид. дім “Персонал”. С. 89-94.

4. Закон України "Про місцеве смаоврядування в Україні” від 21 липня 1997 р. № 280/97-ВР//ВВР України. 1997.

5. Конституція України: прийнята 28 червня 1996 р. // ВВР України. 1996. № 30. 78 c.

6. Утвенко В. В. Теорія та історія місцевого самоврядування: навч.посібник. Київ. ДП “Вид. дім “Персонал”. 2015. 234 c.

\section{REFERENCES}

1. Bolshakov S. N. (2006). Printsip subsidiarnosti v sovremennom demokraticheskom upravlenii: kontseptualnye podkhody i problemy prakticheskoy realizatsii [The principle of subsidiarity in modern democratic governance: conceptual approaches and problems of practical implementation]. Abstract of Doctor's thesis. Saint Petesburg [in Russian]. 
2. Hovoruk D. M. (n.d.). Poniattia pryntsypu publichnosti ta yoho normatyvnyi aspect [The concept of publicity and its regulatory aspect]. nauka.nueau.org.ua. Retrieved from http://nauka.nueau.org.ua/gow uload//elzbirnik/1/covorun.pdf [in Ukrainian].

3. Dehtiar O. A. (2016). Rol systemy publychnoho upravlennyia v sotsyalnii sfere obshchestva [The role of public administration in the social sphere of society]. Publichne uriaduvannia Public Governance, 1(2), 89-94 [in Ukrainian].

4. Zakon Ukrainy "Pro mistseve samovriaduvannia v Ukraini": vid 21 lypnia 1997 r. [Law of Ukraine "On Local Self-Governance in Ukraine" from July 21, 1997]. (1997). Vidomosti Verkhovnoi Rady Ukrainy - Bulletin of Verkhowna Rada of Ukraine, 24. Art. 170 [in Ukrainian].

5. Konstytutsiia Ukrainy: pryiniata 28 chervnia 1996 r. [Constitution of Ukraine: from June 28 1996]. (1996). Vidomosti Verkhoonoi Rady Ukrainy Bulletin of Verkhowna Rada of Ukraine, 30. Art. 78 [in Ukrainian].

6. Utvenko V. V. (2015). Teoriia ta istoriia mistsevoho samovriaduvannia [Local Self-Government Theory and History]. Kyiv: DP "Vydavnychyi dim "Personal” [in Ukrainian]. 